\title{
PENGEMBANGAN INSTRUMEN TES LITERASI SAINS SISWA PADA TOPIK KEANEKARAGAMAN MAKHLUK HIDUP
}

\author{
Rahmadyah Kusuma Putri ${ }^{{ }^{*}}$ \\ ${ }^{1}$ Yayasan Pendidikan Shafiyyatul Amaliyyah Medan \\ email: rahmadyahkusumaputri@gmail.com
}

\begin{abstract}
Abstrak
Penelitian ini bertujuan untuk menghasilkan instrumen tes literasi sains yang valid dan reliabel pada topik keanekaragaman makhluk hidup. Model pengembangan instrumen tes menggunakan model ADDIE (Analyze, Development, Design, Implementation dan Evaluation). Instrument tes diuji validitas dan realibilitasnya. Validitas instrumen yang dilakukan adalah validitas butir soal, yaitu membandingkan nilai $r$ pada tiap butir soal dengan $r$ product moment. Realibilitas yang dilakukan menggunakan rumus Kuder Richardson 20 (KR-20). Hasil penelitian menunjukkan bahwa 18 butir soal dari instrumen tes terbukti valid, $r_{\text {hitung }}>r_{\text {tabel }}(0.278)(\alpha) 5 \%,(d b=n-2)$. Instrumen tes juga memiliki realibilitas dalam kategori tinggi $\left(r_{11}=0.859\right)$.
\end{abstract}

Kata kunci: instrumen tes, keanekaragaman makhluk hidup, literasi sains, model ADDIE

\begin{abstract}
This study aims to produce valid and reliable scientific literacy test instruments on the topic of diversity of living things. The test instrument development model uses the ADDIE model (Analyze, Development, Design, Implementation and Evaluation). The test instrument was tested for validity and reliability. The validity of the instrument is the validity of the items, comparing the value of $r$ on each item with $r$ product moment. Reliability was carried out using the Kuder Richardson 20 formula (KR-20). The results showed that 18 items from the test instruments proved valid, $r_{\text {count }}>r_{\text {table }}(0.278)$ $(\alpha) 5 \%,(d b=n-2)$. Test instruments also have high reliability $\left(r_{11}=0.859\right)$.
\end{abstract}

Keywords: ADDIE model, diversity of living things, scientific literacy, test instruments 


\section{PENDAHULUAN}

Konsep merdeka belajar mengusung kemampuan literasi menjadi salah satu komponen penilaian. Akar kata literasi berasal dari bahasa latin litera (huruf). Secara sederhana, literasi diartikan sebagai kemampuan seseorang untuk membaca dan menulis. Literasi melibatkan serangkaian kemampuan kognitif, pengetahuan bahasa tulis dan lisan, pengetahuan tentang genre dan kebudayaan (Kern, 2000). Literasi tidak hanya berupa tulisan, namun juga berbentuk visual, maupun audiovisual (Iriantara, 2017).

Terdapat beberapa jenis kemampuan literasi yang dikembangkan di ranah pendidikan abad 21, salah satunya yaitu literasi sains. Literasi sains adalah kemampuan menggunakan pengetahuan sains, mengidentifikasi masalah, dan menarik kesimpulan berdasarkan bukti-bukti ilmiah, untuk memahami dan menarik kesimpulan tentang alam dan perubahannya sebagai akibat aktivitas manusia(Lokan dkk, 2008). Lima aspek literasi sains terdiri atas peran sains, berpikir dan bekerja secara ilmiah, sains dan masyarakat, matematika dalam sains, serta motivasi dan kepercayaan terhadap sains (Fives dkk, 2014).

Literasi sains erat kaitannya dengan kemampuan siswa dalam memahami lingkungan hidup dan masalah pada masyarakat modern yang sangat tergantung dengan teknologi serta perkembangan ilmu pengetahuan atau sains (Bybee, 2011). Penilaian literasi sains secara Internasional dilakukan oleh Organisation for Economic Co-operation and Development (OECD) dalam bentuk Programe for International Students (PISA) terhadap 65 negara, terdiri dari negara maju dan negara berkembang. Penilaian PISA diadakan setiap 3 tahun sekali sejak tahun 2000. PISA menguji akademis siswa yang berusia 15 tahun, mencakup kemampuan kognitif, keahlian siswa di bidang Reading, Matematika dan Scientific Literacy. PISA mendefinisikan literasi sains sebagai kemampuan untuk menggunakan pengetahuan sains dalam isu-isu yang berkembang di masyarakat, menjelaskan fenomena ilmiah, mengevaluasi dan merancang penyelidikan ilmiah dan mengambil kesimpulan berdasarkan buktibukti dalam rangka memahami serta membuat keputusan berkenaan dengan alam dan perubahannya akibat aktivitas manusia sehingga menjadi masyarakat yang reflektif (OECD, 2012). PISA menetapkan komponen proses sains dalam penilaian literasi sains, yaitu:

1) Mengidentifikasi isu ilmiah, yaitu mengenal isu yang mungkin diselidiki secara ilmiah, mengidentifikasi kata-kata kunci untuk informasi ilmiah, mengenal ciri khas penyelidikan ilmiah.

2) Menjelaskan fenomena ilmiah, yaitu mengaplikasikan pengetahuan sains dalam situasi yang diberikan, mendeskripsikan atau menafsirkan fenomena dan memprediksi perubahan, mengidentifikasi deskripsi, eksplanasi, dan prediksi yang sesuai.

3) Menggunakan bukti ilmiah, yaitu menafsirkan bukti ilmiah dan menarik kesimpulan, memberikan alasan untuk mendukung atau menolak kesimpulan dan mengidentifikasikan asumsi-asumsi yang dibuat dalam mencapai kesimpulan, mengomunikasikan kesimpulan terkait bukti dan penalaran dibalik kesimpulan 
dan membuat refleksi berdasarkan implikasi sosial dari kesimpulan ilmiah.

Literasi sains dapat ditingkatkan di sekolah melalui pembelajaran saintifik (Asyhari, 2015), pembelajaran menggunakan bahan ajar berbasis inkuiri (Asyhari \& Clara, 2017; Komalasari dkk, 2019) pembelajaran menggunakan bahan ajar berbasis socio-scientific issue (Nazilah dkk., 2019), maupun kegiatan pembelajaran field trip (Dinata dkk, 2018). Guru, sebagai perancang pembelajaran memiliki kompetensi dalam menyusun instrumen penilaian untuk keterampilan tertentu. Hasana dkk (2017) dalam penelitiannya mengembangkan instrumen tes literasi sains untuk topik sistem ekskresi dan koordinasi, instrumen tes tersebut dapat digunakan untuk mengukur tingkat literasi siswa pada topik spesifik serta meningkatkan kemampuan literasi siswa. Guru dalam hal ini dapat mengembangkan instrumen tes literasi sains yang sesuai dengan topik yang sedang dipelajari siswa. Topik keanekaragaman makhluk hidup merupakan topik dasar dalam pelajaran biologi di tingkat sekolah menengah. Topik keanekaragaman makhluk hidup mencakup pengetahuan tentang jenis jenis makhluk hidup serta perannya di ekosistem.

Terdapat muatan literasi sains dalam topik ini, salah satunya yaitu menganalisis peran makhluk hidup terhadap permasalahan lingkungan, namun belum ada instrumen literasi sains yang berkaitan dengan topik keanekaragaman makhluk hidup. Oleh karena itu, penelitian ini bertujuan untuk mengembangkan instrumen literasi sains untuk topik keanekaragaman makhluk hidup.

\section{METODE}

Pengembangan instrumen tes
literasi sains pada penelitian ini
menggunakan model pengembangan
ADDIE (Branch, 2009). Tahapan ADDIE terdiri dari: 1) Analyze (Analisis), 2) Design (Perancangan), 3) Development (Pengembangan), 4) Implementation (Penerapan) dan 5) Evaluation (Evaluasi). Tahap Analyze (Analisis) yang dilakukan meliputi analisis kompetensi inti, analisis kompetensi dasar dan menetapkan indikator literasi sains terkait topik keanekaragaman makhluk hidup. Tahap Design (Perancangan) yang dilakukan adalah merancang kisi - kisi instrumen tes. Tahap Development (Pengembangan) yang dilakukan adalah mengembangkan instrumen tes dengan berpedoman pada kisi-kisi dan penyusunan rubrik penilaian. Tahap Implementation (Penerapan) yang dilakukan adalah menguji cobakan instrumen tes kepada siswa SMP Shafiyyatul Amaliyyah Medan kelas VII Tahun Ajaran 2018/2019 sebanyak 50 orang. Tahap Evaluation (Evaluasi) yang dilakukan adalah menilai kesesuaian dan ketepatan tahap Analyze, Design, Development dan Implementation serta menghitung validitas dan realibilitas instrumen tes.

Validitas instrumen yang dilakukan adalah validitas item butir soal, yaitu membandingkan nilai $r$ pada tiap butir soal dengan $r$ product moment. Realibilitas yang dilakukan menggunakan rumus Kuder Richardson 20 (KR-20).

\section{HASIL DAN PEMBAHASAN}




\section{1) Tahap Analyze (Analisis)}

Berdasarkan analisis kompetensi inti aspek kognitif ( $\mathrm{KI} 3$ ) dirumuskan sejumlah kompetensi yang diharapkan dapat dicapai oleh siswa, yaitu memahami pengetahuan (faktual, konseptual, dan prosedural) berdasarkan rasa ingin tahunya tentang ilmu pengetahuan, teknologi, seni, budaya terkait fenomena dan kejadian tampak mata. Selanjutnya dilakukan analisis kompetensi dasar. Kompetensi dasar terkait topik keanekaragaman makhluk hidup (KD 3.2), yaitu mengklasifikasikan makhluk hidup dan benda berdasarkan karakteristik yang diamati. Indikator literasi sains yang diharapkan dapat dicapai siswa adalah: 1) mengidentifikasi kata-kata kunci untuk informasi ilmiah pada topik keanekaragaman makhluk, 2) menafsirkan bukti ilmiah dan menarik kesimpulan dari data yang ditampilkan dan 3) memprediksi perubahan dari fenomena ilmiah yang terjadi.

\section{2) Tahap Design (Perancangan)}

Topik keanekaragaman makhluk dijabarkan menjadi lima subtopik, yaitu : 1) karakteristik kingdom monera, 2) karakteristik kingdom protista, 3) karakteristik kingdom fungi, 4) karakteristik kingdom plantae dan 5) karakteristik kingdom animalia. Karakteristik termasuk ciri - ciri morfologi, fisiologi, siklus hidup dan peran dari anggota kingdom tersebut.

\section{3) Tahap Development (Pengembangan)}

Instrumen tes dikembangkan menjadi 30 butir soal pilihan berganda, dengan rincian sebagai berikut: 1) lima butir soal subtopik karakteristik kingdom monera, 2) delapan butir soal subtopik karakteristik kingdom protista, 3) empat butir soal subtopik karakteristik kingdom fungi, 4) sepuluh butir soal subtopik karakteristik kingdom plantae dan 5) tiga butir soal subtopik karakteristik kingdom animalia. Terdapat empat pilihan jawaban pada tiap tiap butir soal. Instrumen tes mencakup domain kognitif C1 sampai C5, yaitu pengetahuan (C1), pemahaman (C2), aplikasi (C3), analisis (C4) dan evaluasi (C5). Instrumen tes juga mencantumkan teks dan data yang diambil dari sumber primer. Skor untuk jawaban yang benar pada setiap butir soal adalah satu dan skor untuk jawaban yang salah adalah nol.

\section{4) Tahap Implementation (Penerapan)}

Instrumen tes diuji cobakan kepada siswa SMP Shafiyyatul Amaliyyah Medan kelas VII Tahun Ajaran 2018/2019 sebanyak 50 orang. Siswa tersebut telah mempelajari topik keanekaragaman makhluk hidup selama 8 JP ( $8 \times 40$ menit) dalam satu semester.

\section{5) Tahap Evaluation (Evaluasi)}

Pengembangan instrumen tes literasi sains untuk topik karakteristik makhluk hidup dievaluasi pada setiap tahap. Tahap analyze yang dilakukan telah sesuai dengan kurikulum yang berlaku. Instrumen tes yang disusun pada tahap development sesuai dengan kisi - kisi yang dirumuskan pada tahap design. Tahap implementation yang dilakukan berjalan secara kondusif. Hasil evaluasi terhadap tahap implementation, diperoleh bahwa terdapat delapan belas butir soal yang valid $r_{\text {hitung }}>r_{\text {tabel }}(0.278)(\alpha) 5 \%,(d b=n-2)$ (Tabel 1).

\begin{tabular}{ccccc}
\multicolumn{2}{l}{ Tabel 1. Validitas Butir Soal } \\
$\begin{array}{c}\text { Nomor } \\
\text { soal }\end{array}$ & subtopik & rhitung & rtabel & Ket. \\
\hline 1 & & 0.401 & & Valid \\
2 & Karakteristik & 0.341 & 0.278 & Valid \\
3 & Kingdom Monera & 0.343 & & Valid \\
5 & & 0.334 & & Valid \\
\hline
\end{tabular}




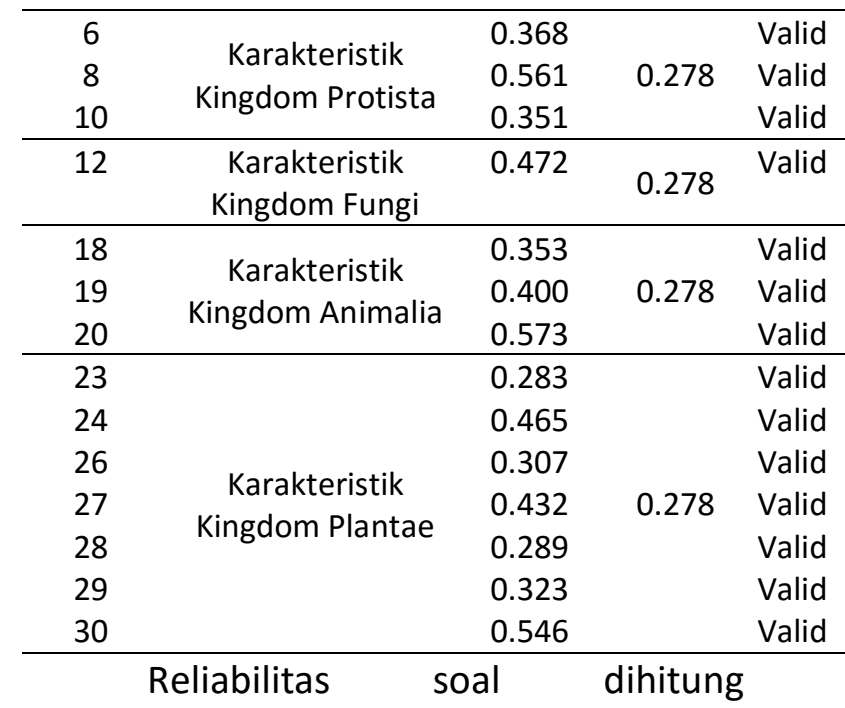

menggunakan rumus KR-20 dengan

kriteria sebagai berikut: $r_{11} \geq 0.70$ (reliabilitas tinggi) dan $r_{11} \leq 0.70$ (reliabilitas rendah). Hasil hitung koefisien reliabilitas instrument tes adalah $r_{11}=0.859$. Ini membuktikan bahwa instrumen tes memiliki reliabilitas tinggi.

Instrumen tes literasi sains yang dikembangkan disusun berdasarkan indikator penilaian literasi sains PISA, yaitu: 1) mengidentifikasi kata-kata kunci untuk informasi ilmiah, 2) menafsirkan bukti ilmiah dan menarik kesimpulan dari data yang ditampilkan dan 3) memprediksi perubahan dari fenomena ilmiah yang terjadi. Bentuk butir soal pada instrumen tes literasi yang dikembangkan bervariasi. Butir soal nomor 1 berkaitan dengan karakteristik kingdom monera, dapat dilihat pada Gambar 1.

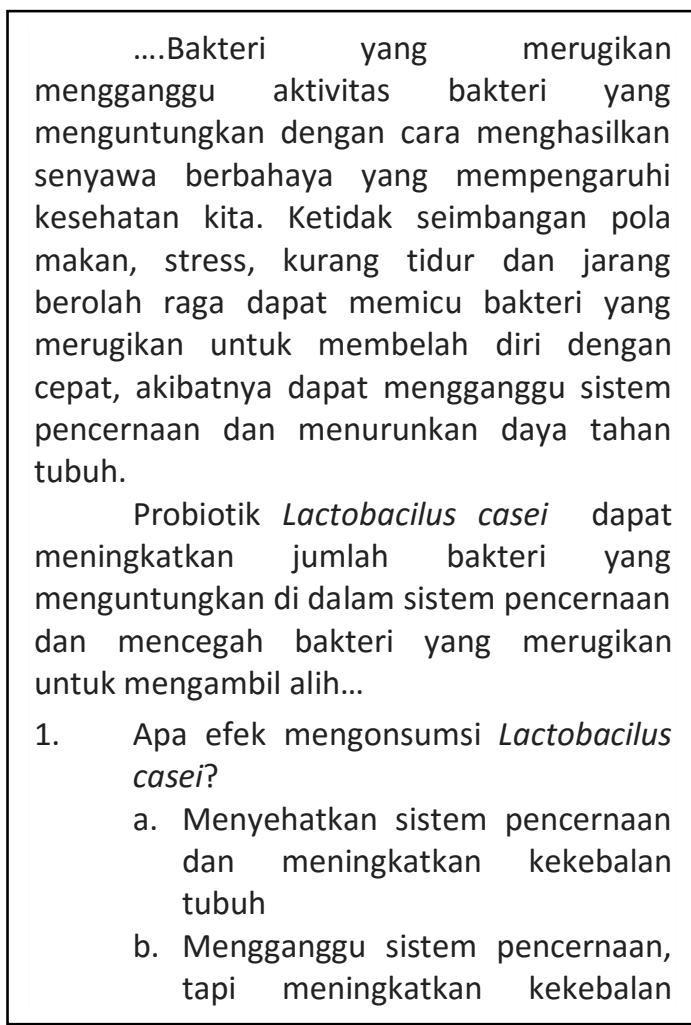

Gambar 1. Cuplikan Butir Soal Nomor 1 Instrumen Tes Literasi Sains untuk Indikator Literasi Sains 1

Butir soal nomor 1 diawali dengan teks mengenai peran probiotik bagi tubuh. Teks ini membantu siswa untuk memunculkan kemampuan kognitif C2 (Pemahaman). Indikator literasi sains yang diujikan pada soal ini adalah indikator 1 , yaitu siswa dapat mengidentifikasi katakata kunci untuk informasi ilmiah. Kata kunci tersebut adalah probiotik. Pemahaman siswa tentang kata kunci ini akan membantunya dalam menjawab soal. Selain teks, kemampuan literasi sains juga dapat digali menggunakan bagan alir yang dapat dilihat pada Gambar 2. 


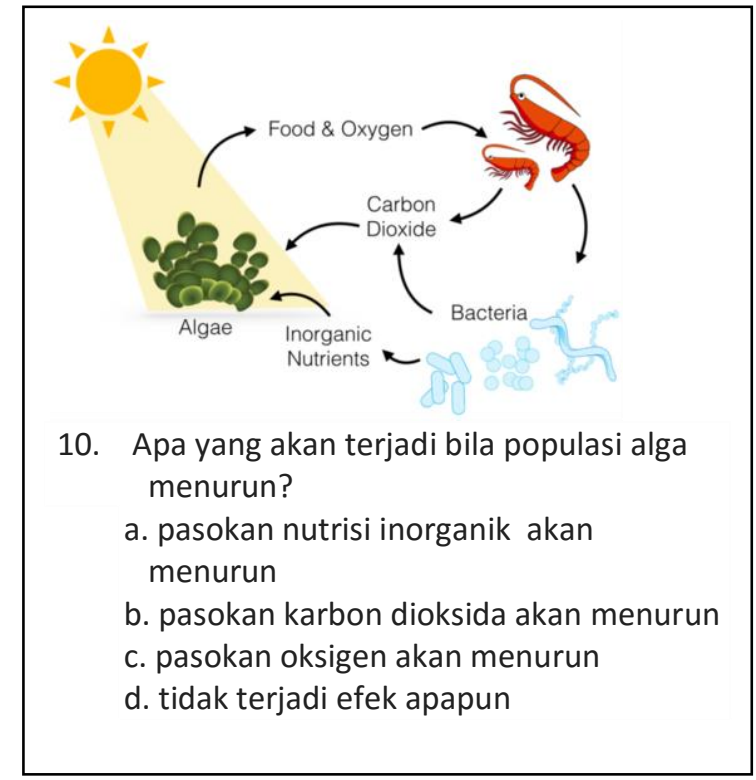

Gambar 2. Cuplikan Butir Soal Nomor 10 Instrumen Tes Literasi Sains untuk Indikator Literasi Sains 3

Butir soal nomor 10 menggali keterampilan siswa dalam membaca bagan alir, ini juga berkaitan dengan kemampuan kognitif siswa C4 (Analisis). Kemampuan literasi sains yang dituntut dari soal ini adalah memprediksi perubahan dari fenomena ilmiah yang terjadi, yaitu memprediksi pengaruh dari menurunnya populasi alga. Siswa dapat menganalisis peran alga dengan menghubungkan simbol-simbol yang terdapat pada bagan alir. Pengetahuan dasar yang dibutuhkan siswa adalah prinsip dasar fotosintesis yang disimbolkan dengan adanya sinar matahari pigmen hijau pada alga. Selanjutnya, bentuk soal yang dikembangkan berupa ilustrasi, seperti yang ditunjukkan pada butir soal nomor 12, yaitu berkaitan dengan karakteristik kingdom fungi dapat dilihat pada Gambar 3.

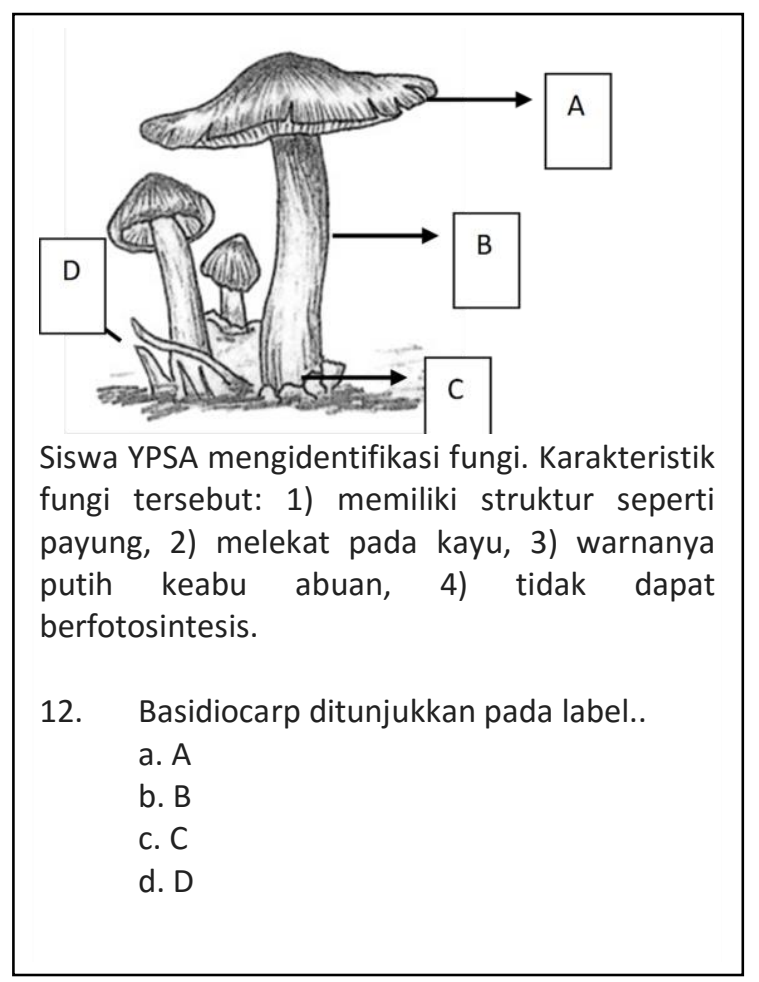

Gambar 3. Cuplikan Butir Soal Nomor 12 Instrumen Tes Literasi Sains untuk Indikator Literasi Sains 1

Butir soal nomor 12 menggali keterampilan siswa dalam membaca ilustrasi, ini juga berkaitan dengan kemampuan kognitif siswa C2 (Pemahaman). Kemampuan literasi sains yang dituntut dari soal ini adalah dapat mengidentifikasi kata-kata kunci untuk informasi ilmiah, yaitu istilah basidiocarp. Bentuk soal literasi sains juga juga dapat berupa bagan informasi. Seperti yang ditunjukkan pada butir soal nomor 28, yaitu berkaitan dengan karakteristik kingdom plantae, dapat dilihat pada Gambar 4. 


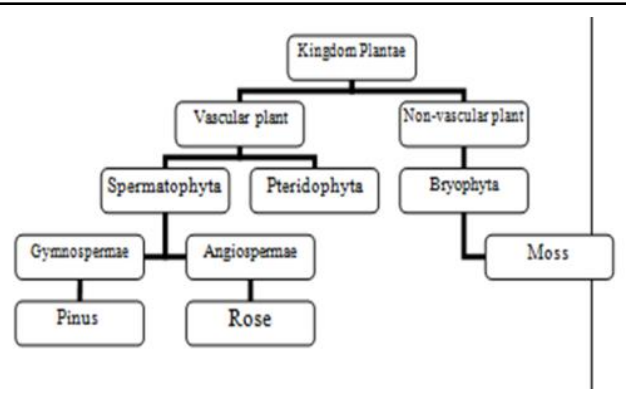

28. Manakah pernyataan di bawah ini yang salah tentang pinus?

a. Pinus memiliki vascular bundle (xylem dan phloem)

b. Pinus memiliki bunga

c. Pinus tidak memiliki vascular bundle (xylem dan phloem)

d. Pinus termasuk kedalam kingdom plantae

Gambar 4. Cuplikan Butir Soal Nomor 28 Instrumen Tes Literasi Sains untuk Indikator Literasi Sains 2

Butir soal nomor 28 menggali keterampilan siswa dalam membaca bagan informasi, ini juga berkaitan dengan kemampuan kognitif siswa C3 (Aplikasi). Kemampuan literasi sains yang dituntut dari soal ini adalah menafsirkan bukti ilmiah dan menarik kesimpulan dari data yang ditampilkan. Data yang ditampilkan menunjukkan hubungan antara karakteristik anggota kingdom plantae. Pengembangan Instrumen tes literasi sains ini memiliki kelebihan dan kelemahan. Kelebihan instrumen tes literasi sains yang dikembangkan adalah spesifik dan sesuai dengan topik yang dipelajari siswa. Instrumen tes ini mampu menggali kemampuan berpikir kognitif yang digunakan untuk memunculkan kemampuan literasi sains. Rahayuni (2016) menyatakan bahwa kemampuan berpikir tingkat tinggi siswa berkorelasi kuat dengan kemampuan literasi sains. Siswa yang memiliki kemampuan berpikir tingkat tinggi, cenderung memiliki kemampuan literasi sains yang tinggi pula (Cahyana dkk, 2017). Sehingga, dalam menjawab soal pada instrumen ini diperlukan dua kemampuan sekaligus, yaitu kognitif dan literasi sains.

Penilaian literasi sains yang dijadikan indikator pengembangan instrumen tes bersumber dari PISA. Sehingga diharapkan instrumen ini dapat menjadi latihan bagi siswa dalam mengerjakan tes serupa. Kelemahan instrumen tes literasi sains yang dikembangkan adalah belum diuji kepraktisan dan keterbacaan oleh siswa dan validator ahli.

\section{PENUTUP}

\section{Kesimpulan}

Produk instrumen tes literasi sains yang dikembangkan sudah valid dan reliabel, sehingga dapat dimanfaatkan oleh guru untuk mengetahui kemampuan literasi siswa, khususnya pada topik keanekaragaman makhluk hidup. Namun perlu dilakukan penelitian lebih lanjut terkait kepraktisan dan keterbacaan instrumen tes kepada siswa dan validator ahli.

\section{DAFTAR PUSTAKA}

Asyhari, A. (2015). Profil Peningkatan Kemampuan Literasi Sains Siswa Melalui Pembelajaran Saintifik. Jurnal IImiah Pendidikan Fisika Al-Biruni, 4(2), 179.

Asyhari, A., \& Clara, G. P. (2017). Pengaruh Pembelajaran Levels of 
Inquiry Terhadap Kemampuan Literasi Sains Siswa. Scientiae Educatia, 6(2), 87.

Bybee, R., \& M. (2011). Scientific literacy and student attitudes: perspectives from PISA 2006 science. International Journal of Science Education, 33(1), 7-26.

Cahyana, U., Kadir, A., \& Gherardini, M. (2017). Relasi Kemampuan Berpikir Kritis Dalam Kemampuan Literasi Sains Pada Siswa Kelas Iv Sekolah Dasar. Sekolah Dasar: Kajian Teori Dan Praktik Pendidikan, 26(1), 14-22.

Dinata, A. N., Adisendjaja, Y. H., \& Amprasto, A. (2018). Assimilation: 1(1), 8-13.

Fives, H., Huebner, W., Birnbaum, A.S. \& Nicolich, M. (2014). Developing A Measure of Scientific Literacy For Middle School Students. Science Education, 98(4), 549-580.

Hasana, I., Saptasari, M., \& Wulandari, N. (2017). Pengembangan Instrumen Penilaian Kemampuan Literasi Sains Siswa Kelas XI Materi Sistem Ekskresi dan Koordinasi di SMAN 9 Malang. Jurnal Pendidikan Biologi, 8(2), 5256.

Iriantara, Y. (2017). Media Literasi dan Pendidikan Karakter. Nusantara Education Review, 5(1), 12.

Kern, R. (2000). Literacy and Language Teaching. Oxford University.

Komalasari, B. S., Jufri, A. W., \& Santoso, D. (2019). Pengembangan Bahan Ajar IPA Berbasis Inkuiri Terbimbing untuk Meningkatkan Literasi Sains. Jurnal Penelitian Pendidikan IPA, 5(2), 219.

Lokan, J., Greenwood, L. \& Cresswell, J. (2008). The PISA 2000 Survey of Students' Reading, Mathematical and Scientific Literacy Skills: 15-Up And Counting, Reading, Writing, Reasoning: How Literate are
Australia's Students?

Nazilah, N., Muharrami, L. K., Rosidi, I., Yuniasti, A., \& Wulandari, R. (2019). Pengaruh Bahan Ajar Berbasis SocioScientific Issues Pada Materi Pemanasan Global Terhadap Kemampuan Literasi. Natural Sceince Education Reseach, 2(1), 8-16.

OECD. (2012). Item Submission Guidelines: Scientific Literacy. OECD.

Rahayuni, G. (2016). Hubungan Keterampilan Berpikir Kritis Dan Literasi Sains Pada Pembelajaran Ipa Terpadu Dengan Model Pbm Dan Stm. Jurnal Penelitian Dan Pembelajaran IPA, 2(2), 131. 